\title{
Corrosion Behavior of Mild Steel and SS 304L in Presence of Dissolved Nickel Under Aerated and Deaerated Conditions
}

\author{
Mohd Mobin*, Hina Shabnam \\ Corrosion Research Laboratory, Department of Applied Chemistry, \\ Faculty of Engineering and Technology, Aligarh Muslim University, Aligarh, 202002, India
}

Received: April 25, 2011; Revised: August 8, 2011

\begin{abstract}
In dual purpose water/power co-generation plants, the presence of high concentration of $\mathrm{Cu}$ and $\mathrm{Ni}$ in the re-circulating brine/condensate as a result of condenser tubes corrosion has been attributed as one of the several causes of corrosion damage of flash chamber materials and water touched parts of the boilers. The present investigation deals with the effect of dissolved nickel in the concentration range of $10 \mathrm{ppb}$ to $100 \mathrm{ppm}$ on the corrosion behavior of mild steel and SS 304L in two aqueous medium namely, distilled water and artificial seawater. The effect of $\mathrm{pH}$, dissolved oxygen and flow condition of aqueous medium on the corrosion behavior was also monitored. The experimental techniques include immersion test and electrochemical tests which include free corrosion potential measurements and potentiodynamic polarization measurements. The corrosion rate of mild steel and SS 304L under different experimental conditions was determined by weight loss method and spectrophotometric determination of iron ion entered into the test solution during the period of immersion. The $\mathrm{pH}$ of the test solution was also monitored during the entire period of immersion. The left over nickel ions present in the test solution after completion of immersion was also estimated using Atomic Absorption Spectrophotometer. The surface morphology of the corroded steel surface was also examined using scanning electron microscopy (SEM). The results of the studies show that SS 304L largely remains unaffected in both distilled water and artificial seawater under different experimental conditions. However, the effect of nickel on the corrosion behavior of mild steel is quite pronounced and follows interesting trends.
\end{abstract}

Keywords: mild steel, SS 304L, corrosion, nickel ions, immersion tests, electrochemical tests

\section{Introduction}

Plain carbon steels, low and high alloy steels, martensitic, austenitic and ferritic stainless steels are some of the materials that are generally used in desalination and power plants for fabrication of various components. During their service life, these materials pick up metal ions from the surrounding environment, which migrates in to the matrix and causes damage ${ }^{1}$. The failure of steel components in desalination or power plants as a result of the deposition of carryover heavy metals/oxides has been a common problem and reported by many authors. The problem may appear in the form of pitting or crevices which act as initiators of stress corrosion in the form of stress corrosion cracking, corrosion fatigue or intergranular corrosion and ultimately leading to the failure of components.

In seawater processing systems, if dissolved oxygen and $\mathrm{pH}$ are under control, general corrosion is the predominant mode of attack on conventional construction materials such as carbon steel. This form of corrosion is easily controllable and is desirable in the sense that it permits predictive estimates of service life. Pitting, the most detrimental form of attack, is often responsible for the corrosion failures of components in desalination and power plants. In process plants, it accounts at least $90 \%$ of metal damage by corrosion ${ }^{2}$. Though there are several causes of pitting, the attack of certain aggressive anions on the protective oxide film on the metal appears to be most widely referred to in the corrosion literature ${ }^{3,4}$. Contact of steels with heavy metal ions is another cause which has been attributed to pitting ${ }^{5}$. This aspect has been given little attention and is least understood yet has great relevance to seawater desalination and power plants ${ }^{6}$.
In MSF desalination plant, desalinated water is produced by flashing seawater in successive flash chambers under reduced pressure. For flash chambers, carbon steel is the most common material of construction; it is used as such or cladded with stainless steel. In the distillers the recirculating brine generally contains high concentration of $\mathrm{Cu}$ and $\mathrm{Ni}$. The source of $\mathrm{Cu}$ and $\mathrm{Ni}$ is the cupronickel condenser tubes in the distiller which are subjected to vapor phase corrosion leading to the contamination of brine and condensate with $\mathrm{Cu}$ and $\mathrm{Ni}^{7}$. The contamination of brine and condensate with $\mathrm{Cu}$ and Ni may lead to the deposition of these metals on the flash chamber components and may accelerate the corrosion. Further, in dual purpose power/water co-generation plants, the condensate from the desalination plants is returned to the boiler and the carryover $\mathrm{Cu}$ and $\mathrm{Ni}$ are deposited over the water touched parts of the boiler leading to their corrosion $^{8,9}$.

In steam turbines, the deposits along the steam path resulting from the boiler carryover are most problematic. The deposits are detrimental to efficiency of the turbine. A study of the corrosion related problems in steam generating equipments shows that while $26 \%$ of the failures are attributed to pitting; $57 \%$ are caused by deposition on blades formed from high dissolved and suspended solid carryover of steam ${ }^{10}$. A survey of literature indicates that references dealing with effect of heavy metals ions on the corrosion behavior of steels are quite scarce. In recent paper corrosion behavior of carbon steel in presence of $\mathrm{Cu}$ and $\mathrm{Ni}$ was reported ${ }^{11}$. Electrochemical techniques like potentiodynamic polarization, linear polarization resistance and $\mathrm{AC}$ impedance have been used to investigate the effect 
of $\mathrm{Cu}$ and $\mathrm{Ni}$. The microscopic examination of test samples did not show any evidence of localized attack on carbon steel.

The present work is concerned with the effect of $\mathrm{Ni}$ on the corrosion behavior of mild steel and SS 304L under different experimental conditions. The experimental conditions which have been taken into account are the nature of aqueous medium, $\mathrm{Ni}$ ion concentration, $\mathrm{pH}$, oxygen and flow condition. The results of the study shall provide important information about the role of Ni carryover on the failure of components used in desalination and power plant.

\section{Materials and Methods}

\subsection{Preparation of specimens}

Commercial grade mild steel and AISI 304L SS were used for the immersion and electrochemical tests. The composition of steels as analyzed by optical emission spectrophotometer is given in the Table 1 . For immersion tests coupons of dimension $(4.0 \times 3.2 \times 0.13) \mathrm{cm}$ were cut from the sheet. To hold the specimens, a hole of $1.5 \mathrm{~mm}$ diameter was made near the edge. The specimens were then machined and abraded on 180 grit $\mathrm{SiC}$ paper to simulate near service conditions. The abraded specimens were washed and degreased with ethyl alcohol and dried up and then used for immersion tests. Before commencing the immersion, the specimens were subjected to above treatments and freshly used with no further storage. For electrochemical tests circular samples with $1.5 \mathrm{~cm}$ diameter were cut from the mild steel and SS 304L sheets. A conducting wire was spot welded to one face of the specimens for the electrical connection and the specimens were then mounted in a cold setting resin to provide a crevice free mount. The exposed circular face was ground on 180 grit $\mathrm{SiC}$ paper. The ground specimens were washed, degreased and dried up.

\subsection{Preparation of test solutions}

The test solutions were made up with distilled water and artificial seawater. The artificial seawater was prepared in the laboratory following ASTM designation D1141. The composition of artificial seawater is given in Table $2^{12}$. The solutions containing $10 \mathrm{ppb}, 100 \mathrm{ppb}, 1,10,20,30,40$ and $100 \mathrm{ppm}$ of Ni were prepared in distilled water and artificial seawater using analar grade $\mathrm{CDH}$ chemicals. The $\mathrm{pH}$ of the solutions was adjusted using $\mathrm{NH}_{4} \mathrm{OH}$ and $\mathrm{CH}_{3} \mathrm{COOH}$. For test solution made up with distilled water a $\mathrm{pH}$ of 4.0, 6.5 and 8.5 was maintained whereas for the test solution made up with artificial seawater a $\mathrm{pH}$ of 8.2 was maintained.

\subsection{Immersion test procedures}

Immersion tests were performed in accordance with ASTM designation G31-72 (Re-approved 1990). After taking the initial weight and dimensions, the coupons were hanged in the test solution containing varying concentration of $\mathrm{Ni}$ ions, with the help of a nylon thread. To avoid the galvanic and crevice corrosion the coupons were loosely tied with the nylon thread. A blank experiment was also carried out for the comparison purpose. The immersion tests were carried out under both static and dynamic conditions. Under static condition, the immersion tests were carried out under both aerated and deaerated conditions. Under aerated condition the tests runs were of 24,360 and 720 hours duration for mild steel and 720, 4320 and 8760 hours durations for SS 304L. However, under deaerated condition the tests runs were of 12 hours duration. Under dynamic conditions the runs were of 24 hours duration. After completion of the immersion test, the specimens were taken out and cleaned following ASTM designation G1-90 and observed for any localized attack. The average corrosion rate was determined using the following relationship:

$$
\text { Corrosionrate }(m p y)=\frac{534 W}{\rho A T}
$$

Where, $\mathrm{W}=$ mass loss in $\mathrm{mg} ; \mathrm{A}=$ area in inch $^{2} ; \mathrm{T}=$ time of exposure in hours and $\rho=$ density in $\mathrm{g} \cdot \mathrm{cm}^{-3}$

\subsection{Solution analysis of metal ions}

Corrosion rate of mild steel and SS 304L was also measured from the determination of total iron ions $\left(\mathrm{Fe}^{2+} / \mathrm{Fe}^{3+}\right)$ entered into the test solution during the course of corrosion. The analysis was performed spectrophotometrically using Elico-SL-169 UV- visible spectrophotometer ${ }^{13,14}$. The corrosion rate was calculated using the following relationship:

$$
\text { Corrosionrate }=\frac{m}{s \times t}\left[g^{-2} h^{-1}\right]
$$

Where, ' $\mathrm{m}$ ' is the mass of corroded metal (calculated from the total iron content determined in the test solution); 's' is the area of the test metal in $\mathrm{m}^{2}$; and ' $\mathrm{t}$ ' is the exposure time in hours.

\subsection{Monitoring of $\mathrm{pH}$}

The $\mathrm{pH}$ of the different test solutions containing mild steel and SS 304L samples were measured on daily basis and continued for one month.

\subsection{Estimation of Ni ions in the test solution}

To find the amount of Ni utilized during the immersion the left over nickel ions present into the test solutions after the completion of immersion was estimated using atomic absorption spectrophotometer. A GBC 902 double beam atomic absorption spectrophotometer was used to determine the concentration of nickel.

\subsection{Electrochemical tests}

The effect of $\mathrm{Ni}$ on the corrosion behavior of mild steel and SS 304L was also investigated by carrying out electrochemical tests like free corrosion potential measurements and potentiodynamic polarization measurements. The tests were carried out in both distilled water and artificial seawater containing varying concentration of nickel at room temperature.

\subsubsection{Free corrosion potential measurement}

The free corrosion potential measurements $\left(\mathrm{E}_{\text {corr }}\right)$ were carried out in absence and presence of varying concentration of $\mathrm{Ni}$ ions at room temperature under static condition. The change in voltage against SCE

\begin{tabular}{|c|c|c|c|c|c|c|c|c|c|c|}
\hline \multirow[t]{2}{*}{ Steel } & \multicolumn{10}{|c|}{$\%$ Composition of elements } \\
\hline & $\mathrm{C}$ & $\mathrm{Si}$ & $\mathrm{Mn}$ & $\mathrm{P}$ & $\mathrm{S}$ & $\mathrm{Cr}$ & $\mathrm{Ni}$ & Mo & $\mathrm{Cu}$ & $\mathrm{Fe}$ \\
\hline Mild steel & 0.206 & 0.004 & 0.166 & 0.028 & 0.044 & 0.078 & 0.088 & 0.114 & 0.052 & Bal \\
\hline AISI 304L & 0.048 & 0.440 & 1.587 & 0.028 & 0.007 & 18.002 & 7.635 & 0.353 & 0.326 & Bal \\
\hline
\end{tabular}

Table 1. Composition of steel as analyzed by optical emission spectrometer. 
Table 2. Chemical compositions of artificial seawater ${ }^{10}$.

\begin{tabular}{cc}
\hline Compound & Concentration $\left(\mathrm{g} . \mathrm{L}^{-1}\right)$ \\
\hline $\mathrm{NaCl}$ & 24.53 \\
$\mathrm{MgCl}_{2}$ & 5.20 \\
$\mathrm{Na}_{2} \mathrm{SO}_{4}$ & 4.09 \\
$\mathrm{CaCl}_{2}$ & 1.16 \\
$\mathrm{KCl}$ & 0.695 \\
$\mathrm{NaHCO}_{3}$ & 0.201 \\
$\mathrm{KBr}_{3}$ & 0.101 \\
$\mathrm{H}_{3} \mathrm{BO}_{3}$ & 0.027 \\
$\mathrm{SrCl}_{2}$ & 0.025 \\
$\mathrm{NaF}$ & 0.003 \\
\hline
\end{tabular}

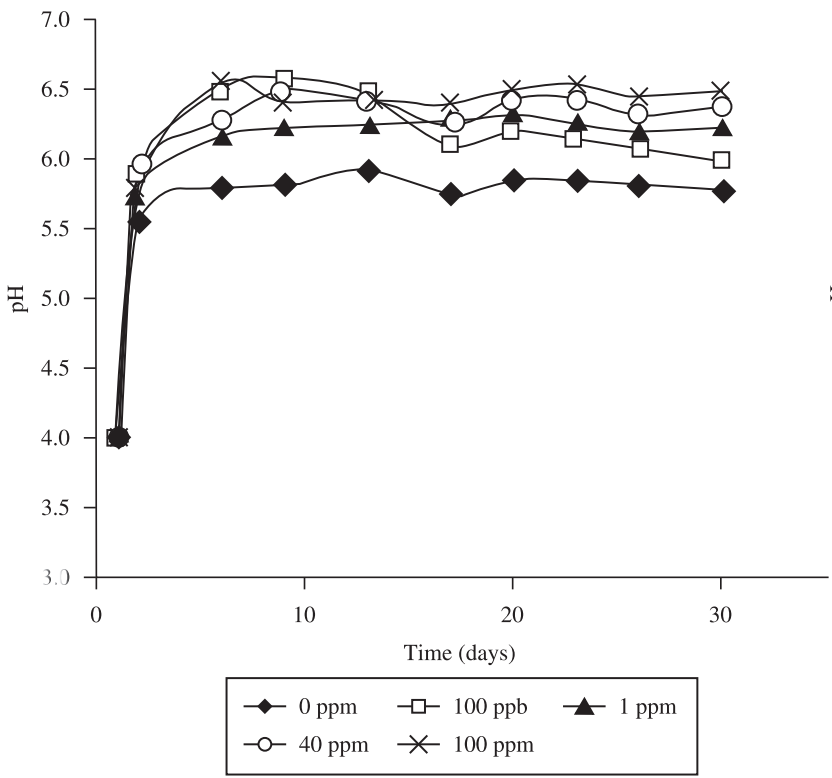

(a)

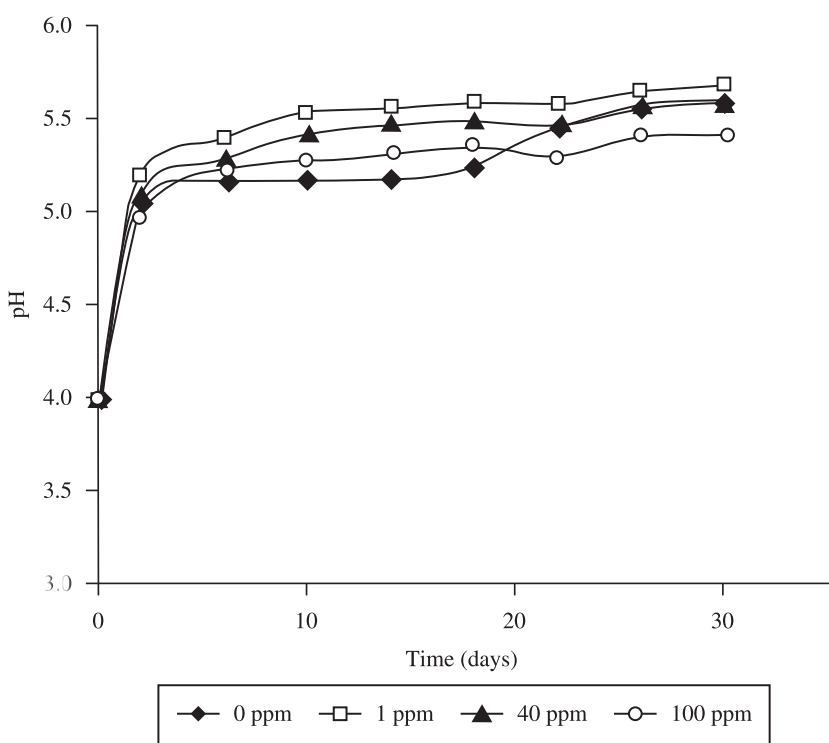

(c) used as reference electrode was plotted vs. time. The steel specimen was connected to a wire having alligator clip on both the ends. One end of the alligator clip was attached to the steel specimen and placed into the test solution and other end was connected to a multimeter.

\subsubsection{Potentiodynamic polarization measurements}

The potentiodynamic polarization measurements were conducted on EG\&G potentiostat/galvanostat Model 263A. The experiments were carried out using a corrosion cell from EG\&G; model K 0047 , with $\mathrm{Ag} / \mathrm{AgCl}$ electrodes (saturated $\mathrm{KCl}$ ) as reference and $\mathrm{Pt}$ wire as counter electrode. The potentiodynamic polarization measurements were carried out using a scan rate of $0.166 \mathrm{mV} / \mathrm{s}$ commencing at a potential above $250 \mathrm{mV}$ more active than stable open circuit potential. To observe the effect of $\mathrm{Ni}$ in a given aqueous medium potentiodynamic curves were obtained under similar experimental

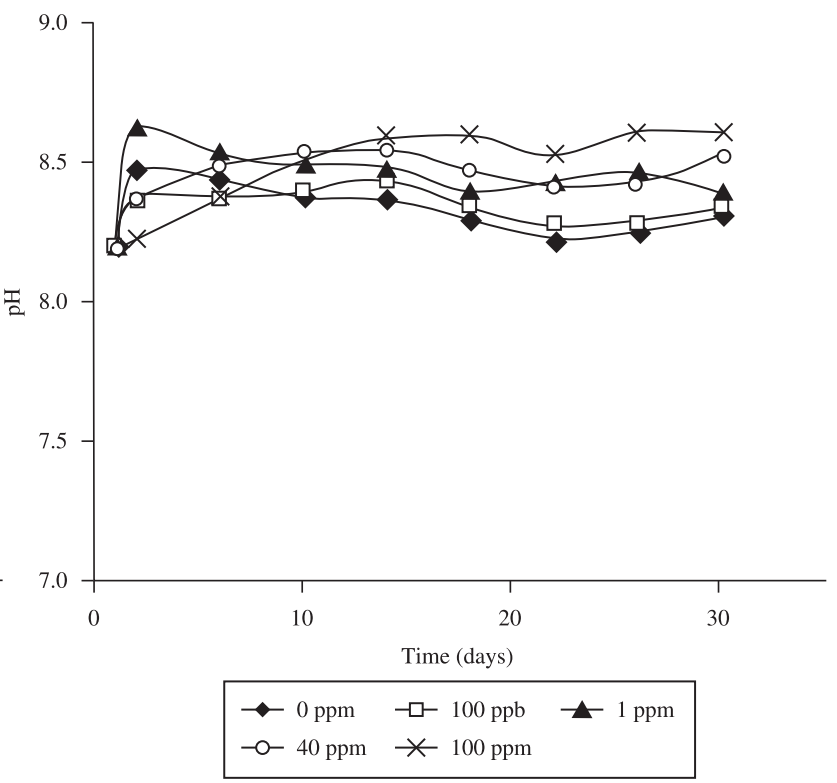

(b)

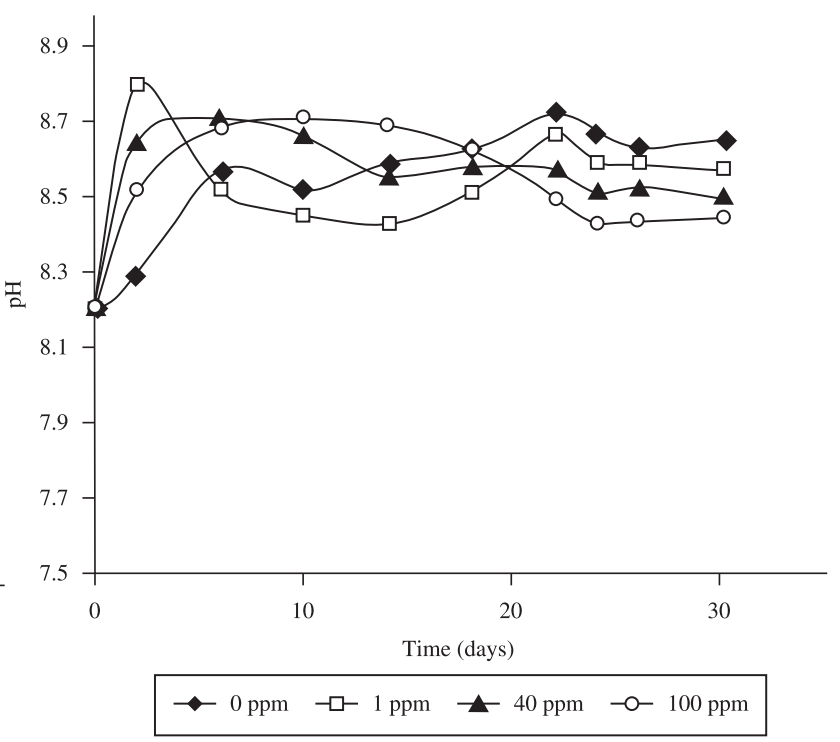

(d)

Figure 1. $\mathrm{pH}$ vs time plot in absence and presence of varying concentration of $\mathrm{Ni}$ for: a) mild steel in distilled water, $\mathrm{pH} 4.0$; b) mild steel in artificial seawater, pH 8.2; c) SS 304L in distilled water, pH 4.0; and d) SS 304L in artificial seawater, $\mathrm{pH}$ 8.2. 
condition except a periodic change in nickel ion concentration. However, before starting the scanning at each concentration, the specimen was stabilized for about 1 hour for attaining a steady state which was shown by a stable potential.

\section{Results and Discussions}

The effect of dissolved nickel ions on the corrosion behavior of mild steel and SS 304L was studied at room temperature under different experimental conditions using immersion and electrochemical techniques. The experimental conditions taken into account are nature of aqueous medium, nickel ion concentration, $\mathrm{pH}$, flow condition and dissolved oxygen. The corrosion behavior of metals under the influence of different environmental variables such as $\mathrm{pH}$, flow velocity, presence of oxidizers etc is quite complex and depends upon the characteristics of metal and the environment to which it is exposed. For mild steel corrosion there is a complex dependence of corrosion rate on $\mathrm{pH}$ of the aqueous solutions. In near neutral $\mathrm{pH}$ range $(5<\mathrm{pH}<9)$, $\mathrm{pH}$ of the solution no longer plays a direct role in corrosion ${ }^{15}$. The major reaction controlling corrosion in most practical application in this $\mathrm{pH}$ range is the reduction of oxygen and the oxidizers, if any, present into the solution. Further, the corrosion processes that are controlled by activation polarization, the solution agitation (dynamic condition) have no effect on the corrosion rate. However, if corrosion process is under cathodic diffusion control, the solution agitation increases the corrosion rate.

Considering the present investigation, at room temperature under static condition, the $\mathrm{pH}$ range selected for the study $(4<\mathrm{pH}<8.5)$ did not affect the corrosion rate of mild steel appreciably. The $\mathrm{pH}$ of the test solutions maintained at different $\mathrm{pH}$ was measured for 30 days and found to vary between 5 to 8.5 Figure 1a,b. The pH of the test solution maintained at $\mathrm{pH} 4$ increased to 5 on the first day of immersion due to the increase in $\mathrm{OH}^{-}$ion concentration as a result of reduction of $\mathrm{H}^{+}$ions. A slightly higher corrosion rate of mild steel at $\mathrm{pH} 4$ may be accounted due to reduction of $\mathrm{H}^{+}$ions in addition to the reduction of oxygen which is the predominant reaction controlling the corrosion rate. In case of SS 304L the $\mathrm{pH}$ of the test solutions largely remained unaffected during the entire period of immersion Figure 1c,d. Under dynamic condition, the corrosion of mild steel is controlled by cathodic diffusion and as a consequence a large increase in corrosion rate was noticed.

Considering the effect of $\mathrm{Ni}$ ions on the corrosion behavior of mild steel and SS 304L, there is negligible or no effect of the presence of $\mathrm{Ni}$ ions on the corrosion rate of SS 304L in both distilled water and artificial sea water. However, the effect of $\mathrm{Ni}$ ions on the corrosion rate of mild steel is quite pronounced and follows interesting trends. In distilled water, a higher concentration of $\mathrm{Ni}$ ions (100 ppm) in the test solution caused a decrease in corrosion rate under both static and dynamic conditions whereas a lower concentration of Ni ions (up to $20 \mathrm{ppm}$ ) caused a slight increase in the corrosion rate Figure 2. In presence of $\mathrm{Ni}$ ions and dissolved oxygen the possible anodic and cathodic reactions are:

Anodic reaction:

$\mathrm{Fe} \rightarrow \mathrm{Fe}^{2+}+2 \mathrm{e}^{-}$

Cathodic reactions:

i) Reduction of oxygen $1 / 2 \mathrm{O}_{2}+\mathrm{H}_{2} \mathrm{O}+2 \mathrm{e}^{-} \rightarrow 2 \mathrm{OH}^{-}$

ii) Reduction of nickel ions $\mathrm{Ni}^{2+}+2 \mathrm{e}^{-} \rightarrow \mathrm{Ni}$

The nickel metal obtained after the reduction of $\mathrm{Ni}$ ions is likely to deposit on the steel surface since the electrode potential of $\mathrm{Ni}\left[\mathrm{E}_{\mathrm{Ni}}^{2+} / \mathrm{Ni}(-0.250 \mathrm{~V})\right]$ is greater than the electrode potential of $\mathrm{Fe}$

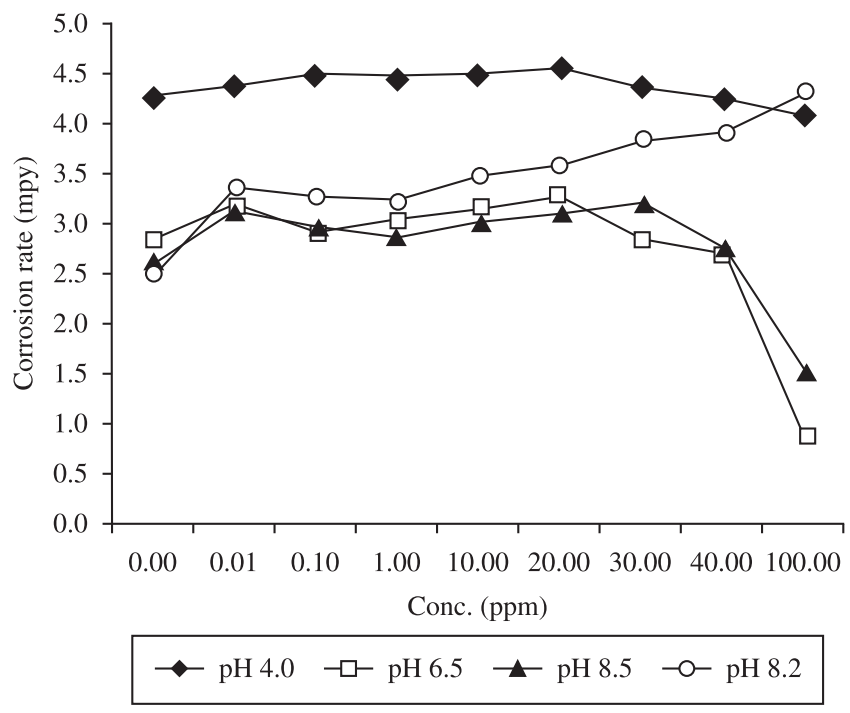

Figure 2. Corrosion rate vs. concentration plot for 1 month duration of mild steel in distilled water and artificial seawater at different $\mathrm{pH}$.

$\left[\mathrm{E}_{\mathrm{Fe}}{ }^{2+} / \mathrm{Fe}(-0.440 \mathrm{~V})\right]$. The deposited $\mathrm{Ni}$ is likely to protect the steel cathodically and causing a decrease in the corrosion rate. However, as the difference in electrode potential of $\mathrm{Fe}$ and $\mathrm{Ni}$ is not very high the nickel is unlikely to form a protective film on steel surface at lower $\left[\mathrm{Ni}^{2+}\right]^{16}$. When $\mathrm{Ni}$ ion concentration reached to a certain value, the reduction reaction involving the reduction of $\mathrm{Ni}$ ions moved forcefully from left to right and greater amount of nickel is deposited on steel. This caused a substantial lowering in the corrosion rate. A higher concentration of $\mathrm{Ni}$ ions in the solution results in the formation of more Ni metal which is likely to deposit on steel surface and form a perfect barrier there by decreasing the rate of corrosion. However, a lower concentration of $\mathrm{Ni}$ ions in the solution is unlikely to form a perfect barrier on the steel surface. This may increase the corrosion rate by accelerating the anodic reaction and forming tiny galvanic cells on the steel surface. To find the amount of $\mathrm{Ni}$ ion consumed during the reduction the left over nickel ions present into the test solutions after the completion of immersion was estimated using atomic absorption spectrophotometer. At lower concentration of $\mathrm{Ni}$ (Ni conc. up to $1 \mathrm{ppm}$ ) all the nickel present into the solution is consumed in the reduction reaction resulting in an increase in the corrosion rate of mild steel. On increasing the concentration above $1 \mathrm{ppm}$ a substantial amount of Ni remains unreacted and was estimated by AAS. The amount of unreacted Ni decreased with increasing exposure period. At highest concentration of Ni (i.e.100 ppm) the value of unreacted $\mathrm{Ni}$ was lowest this support the lower corrosion rates at $100 \mathrm{ppm} \mathrm{Ni}$. The results of corrosion rate as measured by weight loss method are consistent with the corrosion rates measured by spectrophotometric determination of iron ions entered into the test solution during immersion.

Considering the effect of dissolved oxygen on the corrosion behavior of mild steel, in absence of dissolved oxygen the corrosion rate of mild steel is considerably lowered in both distilled water and artificial seawater. The presence of nickel ions under deaerated condition caused an increase in the corrosion rate at lower concentration. However in presence of $100 \mathrm{ppm}$ of $\mathrm{Ni}$ ions a perfect barrier of nickel metal is formed on the surface and corrosion process is completely stopped. Under deaerated condition the lowering in corrosion rate is attributed to the absence of cathodic reaction involving the reduction of oxygen. The only cathodic reaction 


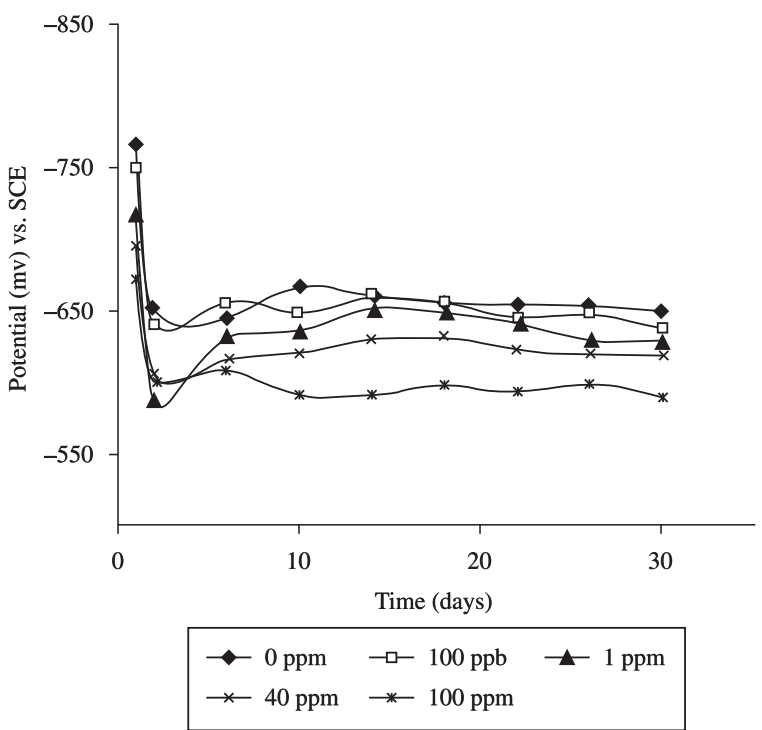

(a)

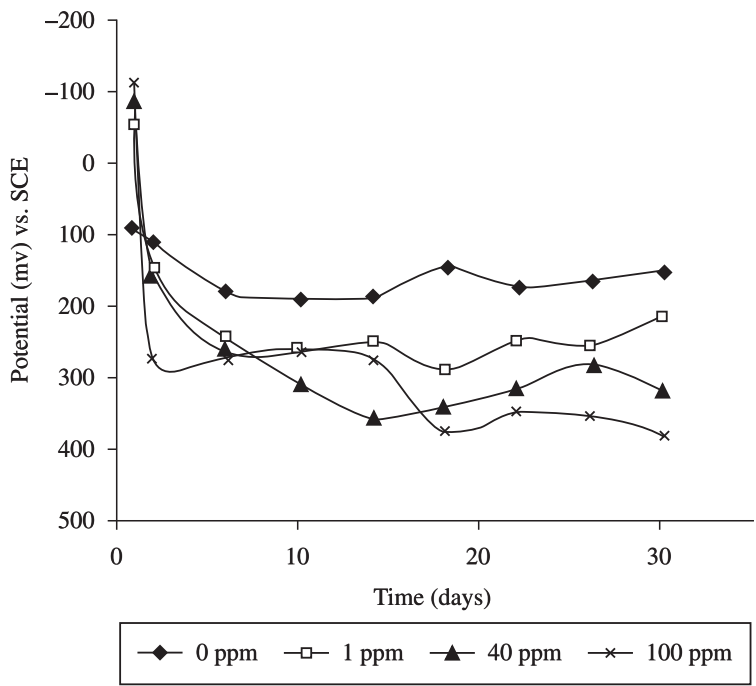

(c)

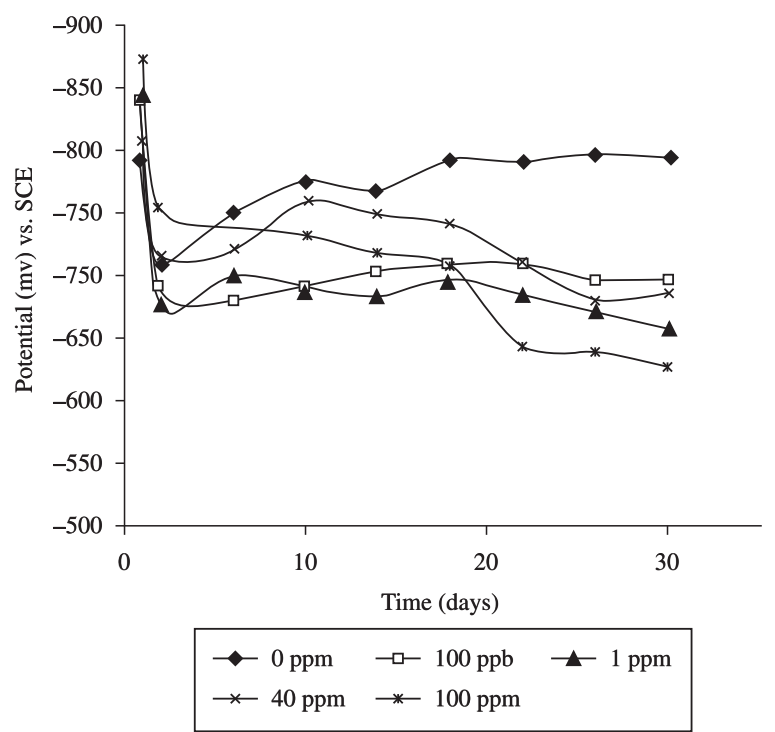

(b)

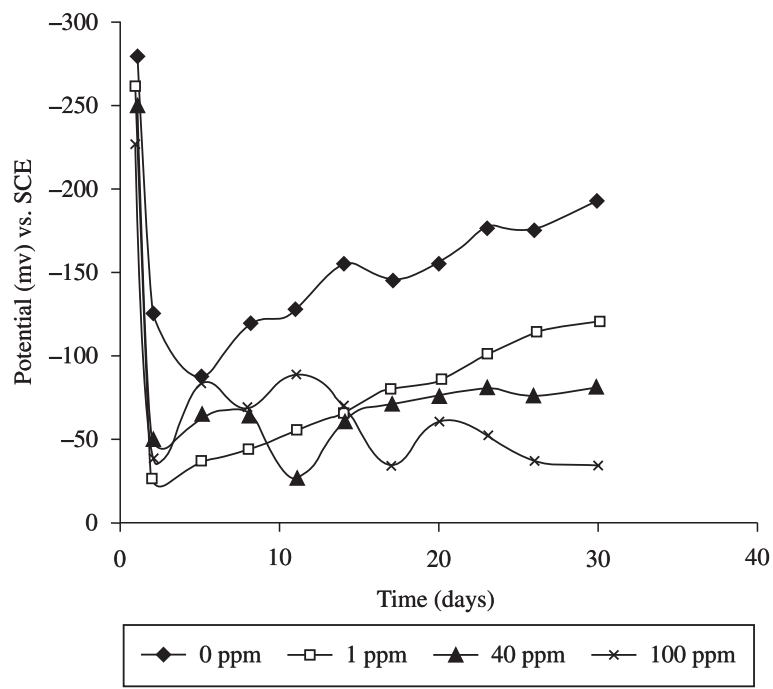

(d)

Figure 3. $E_{\text {arr }}$ vs. time plot in absence and presence of varying concentration of Ni: a) mild steel in distilled water, pH 4.0; b) mild steel in artificial seawater, $\mathrm{pH} 8.2$; c) SS 304L in distilled water, $\mathrm{pH} 4.0$; and d) SS 304L in artificial seawater, $\mathrm{pH} 8.2$.

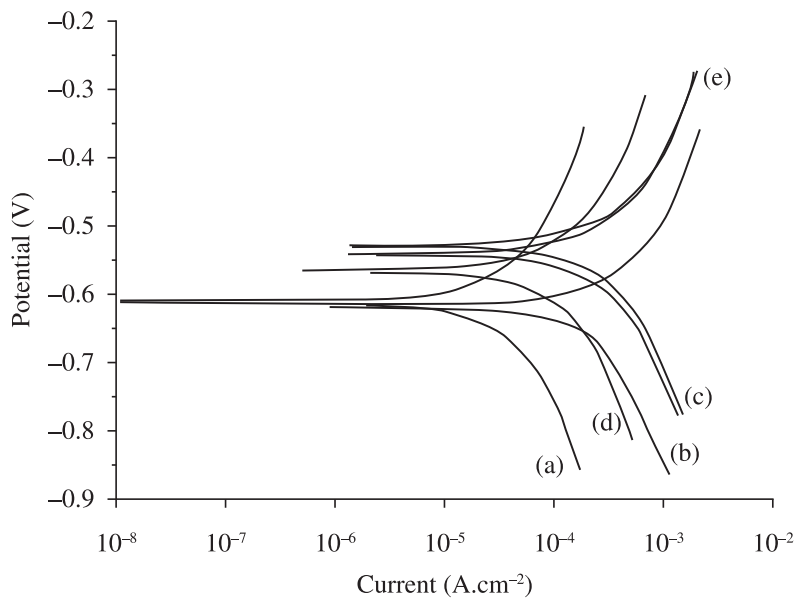

Figure 4. Potentiodynamic polarization curves for mild steel in distilled water $(\mathrm{pH}=4.0)$ in absence and presence of varying concentration of Ni: a) Blank; b) $100 \mathrm{ppb}$; ) $1 \mathrm{ppm}$; $40 \mathrm{ppm}$; and e) $100 \mathrm{ppm}$.

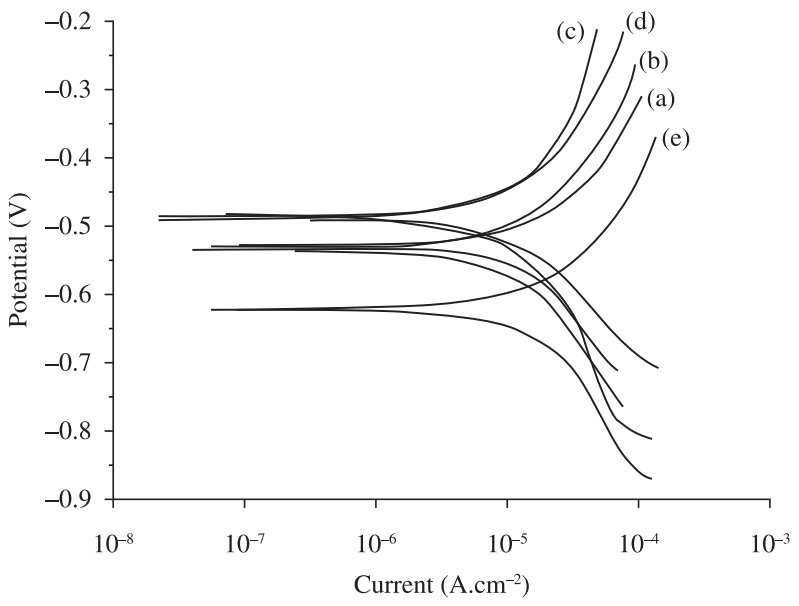

Figure 5. Potentiodynamic polarization curves for mild steel in distilled water $(\mathrm{pH}=8.5)$ in absence and presence of varying concentration of Ni: a) Blank; b) $100 \mathrm{ppb}$; ) $1 \mathrm{ppm}$; $) 40 \mathrm{ppm}$; and e) $100 \mathrm{ppm}$. 


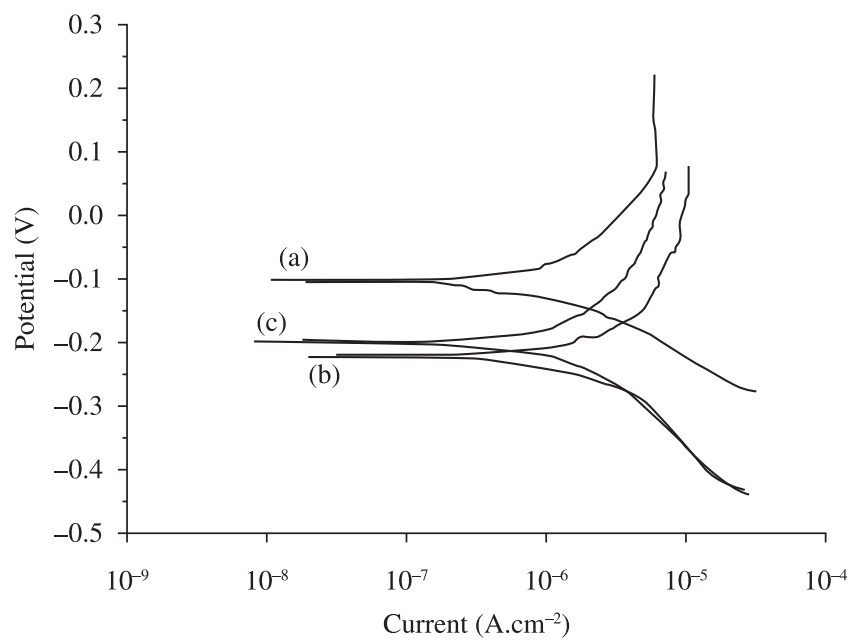

Figure 6. Potentiodynamic polarization curves for SS 304Lsteel in distilled water $(\mathrm{pH}=4.0)$ in absence and presence of varying concentration of $\mathrm{Ni}$ : a) Blank; b) 1 ppm; and c)100 ppm.

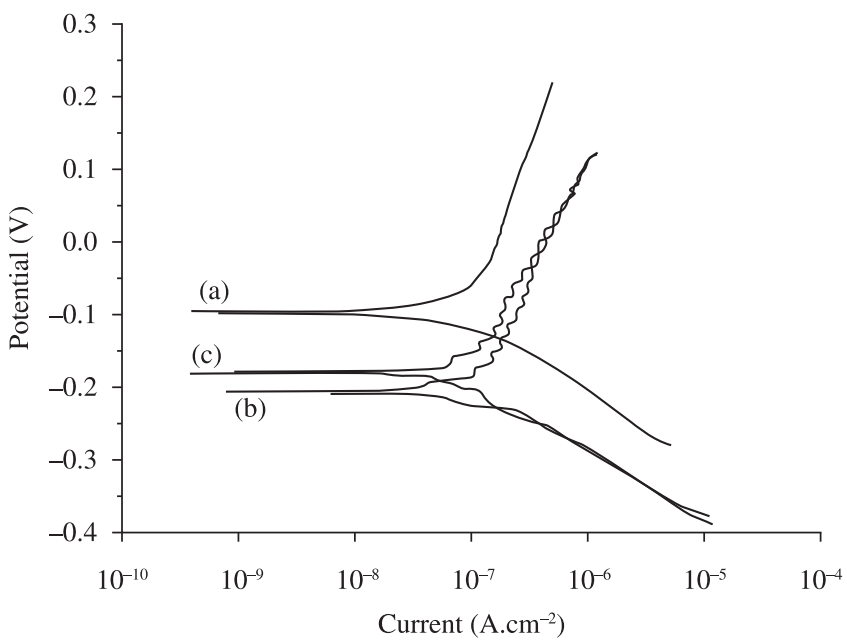

Figure 7. Potentiodynamic polarization curves for SS 304Lsteel in distilled water $(\mathrm{pH}=8.5)$ in absence and presence of varying concentration of $\mathrm{Ni}$ : a) Blank; b) 1 ppm; and c) 100 ppm.

Table 3. Corrosion parameters for mild steel and SS 304L in distilled water and artificial seawater as obtained by potentiodynamic polarization measurements.

\begin{tabular}{|c|c|c|c|c|c|c|}
\hline Alloy & $\begin{array}{l}\text { Aqueous } \\
\text { medium }\end{array}$ & $\mathrm{pH}$ & $\begin{array}{l}\text { Ni ions conc. } \\
(\mathrm{ppm})\end{array}$ & $\mathrm{E}_{\text {corr }}(\mathrm{mV})$ & $\mathrm{I}_{\text {corr }}\left(\mathrm{A} \cdot \mathrm{cm}^{-2}\right)$ & $\begin{array}{c}\text { Corrosion rate } \\
\text { (mpy) }\end{array}$ \\
\hline \multirow[t]{19}{*}{ Mild steel } & \multirow{14}{*}{$\begin{array}{l}\text { Distilled } \\
\text { water }\end{array}$} & \multirow{5}{*}{4.0} & $0 \mathrm{ppm}$ & -610 & $4.7 \times 10^{-4}$ & 107.7 \\
\hline & & & $100 \mathrm{ppb}$ & -617 & $1.28 \times 10^{-3}$ & 293.3 \\
\hline & & & $1 \mathrm{ppm}$ & -528 & $1.1 \times 10^{-3}$ & 265.3 \\
\hline & & & $40 \mathrm{ppm}$ & -564 & $6.0 \times 10^{-4}$ & 138.1 \\
\hline & & & 100 ppm & -540 & $1.2 \times 10^{-3}$ & 294.9 \\
\hline & & \multirow{4}{*}{6.5} & $0 \mathrm{ppm}$ & -568 & $5.5 \times 10^{-5}$ & 12.7 \\
\hline & & & $100 \mathrm{ppb}$ & -613 & $1.0 \times 10^{-4}$ & 23.4 \\
\hline & & & $1 \mathrm{ppm}$ & -727 & $2.7 \times 10^{-3}$ & 40.6 \\
\hline & & & 100 ppm & -591 & $9.7 \times 10^{-5}$ & 22.3 \\
\hline & & \multirow{5}{*}{8.5} & $0 \mathrm{ppm}$ & -528 & $1.0 \times 10^{-4}$ & 24.2 \\
\hline & & & $100 \mathrm{ppb}$ & -533 & $3.4 \times 10^{-4}$ & 8.0 \\
\hline & & & $1 \mathrm{ppm}$ & -484 & $3.0 \times 10^{-5}$ & 7.0 \\
\hline & & & $40 \mathrm{ppm}$ & -486 & $3.04 \times 10^{-5}$ & 6.9 \\
\hline & & & 100 ppm & -621 & $7.5 \times 10^{-5}$ & 17.2 \\
\hline & \multirow{5}{*}{$\begin{array}{l}\text { Artificial } \\
\text { seawater }\end{array}$} & & $0 \mathrm{ppm}$ & -849 & $2.8 \times 10^{-5}$ & 6.5 \\
\hline & & & $100 \mathrm{ppb}$ & -653 & $8.2 \times 10^{-6}$ & 1.89 \\
\hline & & 8.2 & $1 \mathrm{ppm}$ & -771 & $2.2 \times 10^{-5}$ & 5.16 \\
\hline & & & $40 \mathrm{ppm}$ & -766 & $1.08 \times 10^{-5}$ & 2.48 \\
\hline & & & 100 ppm & -787 & $1.8 \times 10^{-5}$ & 4.27 \\
\hline \multirow[t]{9}{*}{ SS 304L } & \multirow{9}{*}{$\begin{array}{l}\text { Distilled } \\
\text { water }\end{array}$} & \multirow{3}{*}{4.0} & $0 \mathrm{ppm}$ & -102 & $2.5 \times 10^{-6}$ & 0.59 \\
\hline & & & $1 \mathrm{ppm}$ & -175 & $5.2 \times 10^{-6}$ & 1.2 \\
\hline & & & $100 \mathrm{ppm}$ & -204 & $3.3 \times 10^{-6}$ & 0.77 \\
\hline & & \multirow{3}{*}{6.5} & $0 \mathrm{ppm}$ & -151 & $1.0 \times 10^{-7}$ & 0.024 \\
\hline & & & $1 \mathrm{ppm}$ & -196 & $5.42 \times 10^{-6}$ & 0.98 \\
\hline & & & 100 ppm & -204 & $1.47 \times 10^{-6}$ & 0.33 \\
\hline & & \multirow{3}{*}{8.5} & $0 \mathrm{ppm}$ & -97 & $1.3 \times 10^{-7}$ & 0.031 \\
\hline & & & $1 \mathrm{ppm}$ & -204 & $1.57 \times 10^{-7}$ & 0.035 \\
\hline & & & $100 \mathrm{ppm}$ & -182 & $8.6 \times 10^{-7}$ & 0.198 \\
\hline
\end{tabular}




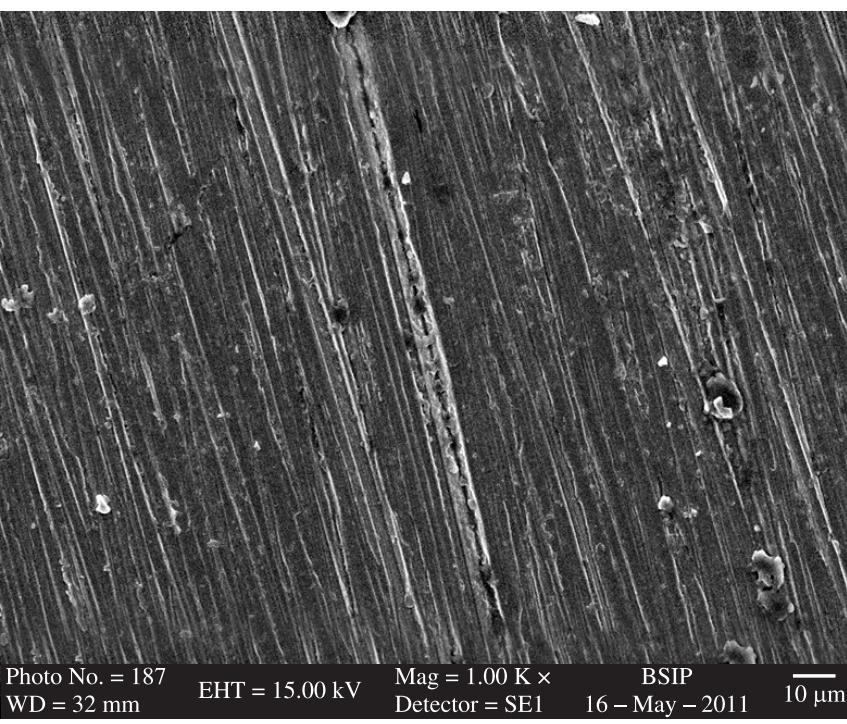

(a)

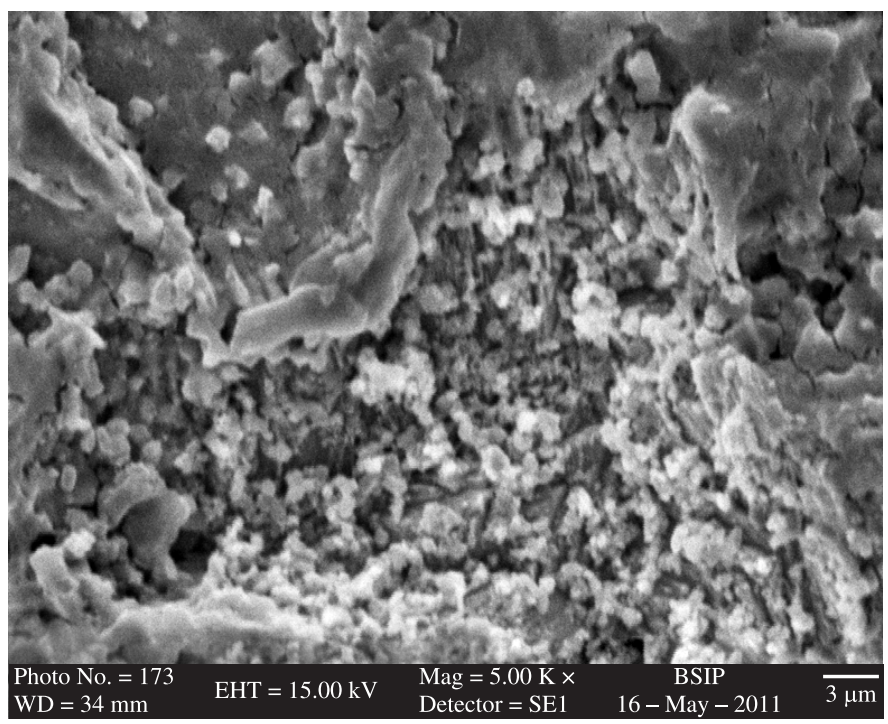

(b)

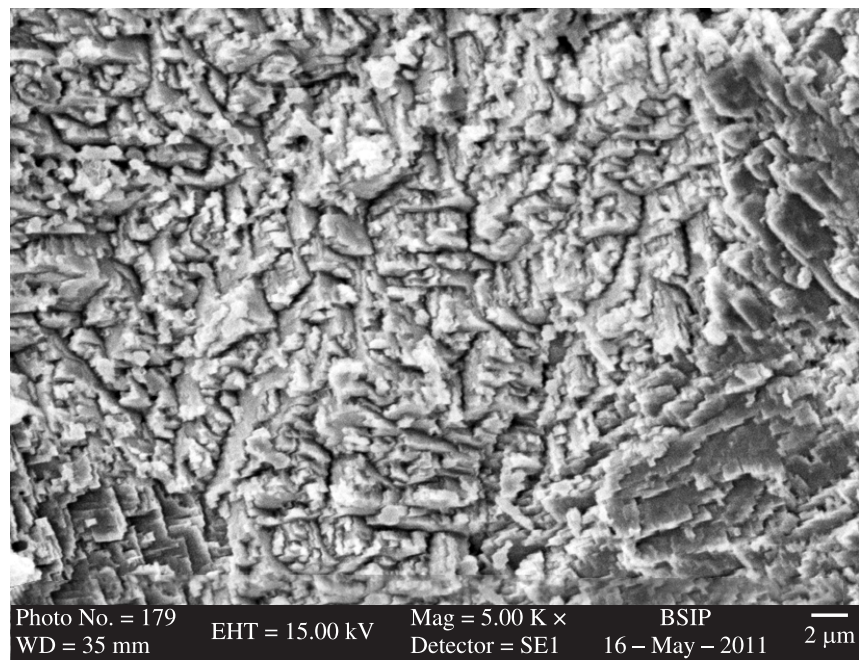

(c)

Figure 8. SEM micrographs of: a) mild steel; b) mild steel immersed in distilled water at pH 6.5 containing 100 ppm Ni ion; and c) mild steel immersed in artificial seawater $\mathrm{pH} 8.2$ containing $100 \mathrm{ppm} \mathrm{Ni}$ ion.

occurring is the reduction of $\mathrm{Ni}$ ions. At $100 \mathrm{ppm}$ of Ni sufficient amount of $\mathrm{Ni}$ ions are reduced to form a perfect barrier on the steel thereby preventing further corrosion of steel.

Considering the results of immersion test for SS 304L, there is negligible or no effect of the presence of $\mathrm{Ni}$ ions on the corrosion rate in both distilled water and artificial seawater. The concentration of $\mathrm{Ni}$ ions in test solution after completion of immersion was estimated. In case of SS 304L immersed in distilled water and artificial seawater nearly all the Ni ions added into the test solution remained unreacted. The observed behavior is due to the absence of anodic reaction as SS 304L remains unaffected in both distilled water and artificial water. Due to the absence of anodic reaction the electrons required for cathodic reactions were not generated and as a result almost all the $\mathrm{Ni}$ ions in the solutions remained unreacted.

The results of immersion tests find support from free corrosion potential measurements. The typical potential vs. time plots for mild steel in distilled water and artificial seawater in absence and presence of $100 \mathrm{ppb}, 1,40$ and $100 \mathrm{ppm}$ of $\mathrm{Ni}$ are shown in Figure $3 \mathrm{a}, \mathrm{b}$. In distilled water at $\mathrm{pH} 4.0$, the initial potential of mild steel is $-766 \mathrm{mV}$; this is followed by a decrease in negative potential till a near steady state was attained at about $-650 \mathrm{mV}$. In presence of $\mathrm{Ni}$ ions a significant ennoblement in $\mathrm{E}_{\text {corr }}$ is observed; an initial decrease in negative potential was observed in presence of $100 \mathrm{ppb}$, 1,40 and $100 \mathrm{ppm}$ of nickel, and a potential below $-650 \mathrm{mV}$ is maintained for the time period extending 30 days. In case of mild steel immersed in artificial sea water the stable potential of around $-800 \mathrm{mV}$ is maintained throughout the entire period. The addition of $\mathrm{Ni}$ ions shifts the $\mathrm{E}_{\text {corr }}$ in more noble direction. In presence of $100 \mathrm{ppb}$, 1,40 and $100 \mathrm{ppm} \mathrm{Ni}$, the potential is reached to above $-650 \mathrm{mV}$. The potential vs. time plots for SS 304L in distilled water and artificial seawater is shown in Figure 3c,d. In general, the presence of $\mathrm{Ni}$ ions shifts the $\mathrm{E}_{\text {corr }}$ of $304 \mathrm{~L}$ SS to a more noble direction in both the aqueous medium under investigation.

The potentiodynamic polarization curves for mild steel and SS $304 \mathrm{~L}$ in distilled and artificial seawater in absence and presence of $\mathrm{Ni}$ ions are shown in (Figures 4-7). The values of $\mathrm{E}_{\text {corr }}, \mathrm{I}_{\text {corr }}$, and corrosion rate as obtained from these curves are shown in Table 3. In general, an increase in $\mathrm{I}_{\text {corr }}$ with increasing $\mathrm{Ni}$ ion concentrations is observed. In 
presence of lower concentration of $\mathrm{Ni}$ ions there was a cathodic shift in $\mathrm{E}_{\text {corr }}$ making the steel surface more active. At $100 \mathrm{ppm} \mathrm{Ni}$, though there was an anodic shift in $\mathrm{E}_{\text {corr }}$ making the steel surface nobler, an increase in the $\mathrm{I}_{\text {corr }}$ value caused a substantial increase in the corrosion rate. The corrosion parameters as obtained by the potentiodynamic polarization measurements are instantaneous and increase in the corrosion rate with increasing $\mathrm{Ni}$ ion concentration can be explained on the basis of additional cathodic reaction involving the reduction of $\mathrm{Ni}$ ions and inability of nickel to form a protective covering on the surface. To observe the effect of $\mathrm{Ni}$ ion on the localized corrosion behavior of steel the surface morphology of the corroded steel surface was also examined using scanning electron microscopy (SEM) (Model: LEO Electron Microscopy Ltd. Cambridge, England) and the micrographs are produced in Figure 8. The SEM micrographs did not show any evidence of localized attack in presence of $\mathrm{Ni}$ ions.

\section{Conclusions}

- The results of immersion tests showed a decrease in the corrosion rate of mild steel with increasing $\mathrm{Ni}$ ion concentration under both static and dynamic conditions. This is attributed to the deposition of reduced $\mathrm{Ni}$ on the steel surface which protected the steel efficiently and caused a decrease in corrosion rate.

- In presence of lower concentration of $\mathrm{Ni}$ ions, the observed increase in corrosion rate is due to the occurrence of two cathodic reactions and absence of a stable protective barrier.

- Under deaerated condition, the presence of $100 \mathrm{ppm}$ of $\mathrm{Ni}$ ions resulted in a perfect barrier and completely stopped the corrosion process.

- SS 304L is unaffected in both distilled and artificial seawater and presence of Ni ions in the medium showed no effect on the corrosion rate.

- The results of immersion tests find support from free corrosion potential measurements. In presence of higher concentration of Ni there is significant ennoblement in the $\mathrm{E}_{\text {corr }}$ of mild steel and SS 304L suggesting the protective role of $\mathrm{Ni}$.

- The corrosion parameters as derived from potentiodynamic polarization measurements showed an increase in the corrosion rate of mild steel with increasing $\mathrm{Ni}$ concentration. This is explained on the basis of instantaneous measurement of the corrosion parameters and rapid rate of electron transfer reactions.

- The microscopic examination of the mild steel and SS 304L coupons subjected to immersion in distilled and artificial seawater did not show any evidence of localized attack in presence of different concentration of Ni ions.

\section{References}

1. Harding K and Bridle DA. Corrosion Measurement and Assessment in Acid Dosed Desalination plants. Desalination. 1979; 28:89-108. http://dx.doi.org/10.1016/S0011-9164(00)80330-6

2. Asphahani AI and Silence WL. Metal Hand Book. ASME Publication; 1987. v. 13, 113 p.

3. Szklarska-Smialowska K. Pitting Corrosion of Metals. Houston: NACE; 1986.

4. Uhlig HH and Revie RW. Corrosion Control - An Introduction to Corrosion Science and Engineering. 3th ed. New York: Wiley; 1985.

5. American Water Work Association - AWWA and DVGW-for Schungsteus. Internal Corrosion of Water Distribution System: Cooperative Research Report. AWWA; 1985. 191 p.

6. Schrieber CF. Measurement and Control Related Corrosion and Scales in Water Desalination Installation, in Measurement of Control in Water Desalination. Amsterdam: N. Lior Ed., Elsevier; 1986. 427 p.

7. Al-Sums EA, Aziz S, Al-Radif A, Said MS and Heikel O. Vapor side Corrosion of Copper base Condenser Tubes of the MSF desalination plants of Abu Dhabi. Desalination. 1994; 97:109. http://dx.doi. org/10.1016/0011-9164(94)00079-4

8. Mobin M, Malik AU, Andijani IN, Al-Muaili F and Al-Hajri M. Premature Water-side Corrosion of Furnace Wall Tubes in a High Pressure Boiler. Materials Performance. 2006; 45(9):44-49.

9. Hargrave RE. Boiler Tube Failures: Case Histories of Steam Blanketing and Under Deposit Corrosion. Materials Performance. 1994; 33:51.

10. Otaker J. Developing Steam Purity Limits. New York: Power; 1989.

11. Mobin M. Electrochemical Studies on the Corrosion Behavior of Carbon Steel in Presence of $\mathrm{Cu}$ and Ni. Portugaliae Electrochimica Acta. 2008; 26(5):449-447. http://dx.doi.org/10.4152/pea.200805449

12. American Society for Testing and Materials - ASTM. ASTM D1141: Standard Specification for Substitute Ocean Water in Annual Book of ASTM Standards 4.0. ASM International; 1996.

13. Vera R, Schrebler R, Cury P, Del RR and Romero H. Corrosion Protection of Carbon Steel and Copper by Polyaniline and Poly(o-methoxyaniline) Films in Sodium Chloride Medium: Electrochemical and Morphological Study. Journal of Applied Electrochemistry. 2007; 37:519-525. http://dx.doi.org/10.1007/s10800-006-9284-y

14. Ansari R and Alikhani AH. Application of Polyaniline/Nylon Composites Coating for Corrosion Protection of Steel. Journal of Coatings Technology. 2009; 6(2):221-227. http://dx.doi.org/10.1007/s11998-008-9140-6

15. American Society for Testing and Materials - ASTM. Metal Hand book. 9th ed. ASM International; 1987. 38 p. 13. Corrosion.

16. Mu GN, Zhao TP, Liu M and Gu T. Effect of Metallic Cations on Corrosion Inhibition of an Anionic Surfactant for Mild Steel. Corrosion. 1996; 52(11). 